\title{
A Study on Blended Learning of High-quality Translation Courses in the Post-epidemic Era
}

\author{
Chunye Yang ${ }^{1}$ \\ ${ }^{1}$ College of Foreign Languages, Wuhan Business University, Wuhan, Hubei, China
}

\begin{abstract}
In 2020, COVID-19 swept the globe. The whole world faced up with unprecedented challenges. For example, millions of students cannot go back to their campus. Chinese government advocated "No suspension for the class!" Thanks to information technologies, universities and colleges started online learning on various online learning applications, such as Tencent Conference, QQ, Rain Class, Chaoxing. Now in the post-epidemic era, we have to think of the influence of information technology and internet on teaching since it makes distance teaching and learning possible. Blended leaning is a good example of combining face-toface instruction and online learning. Blended learning is a popular distance teaching method currently because it provides flexibility to teachers and learners. This paper studied on blended learning of high-quality translation courses so as to highlight merits of blended learning and what factors should be focused with blended learning. "The most commonly quoted benefits are continuous learning, time saved and reduced travel costs ${ }^{[1]}$ ". This paper finds out: blended class is popular; most teachers and students give positive respond to blended classes; developing a high-quality translation courses needs institutions, teachers and students to do a lot. This paper also summarizes the merits of blended learning as: flexibility in learning environments, continuous learning, supplement for face-to-face instruction, and lubricant among institutions, teachers and students. By blending, teachers should focus on the content, new technologies, and effect of face-to-face instruction; students should focus on cultivating critical thinking ability, controlling learning pace and managing time.
\end{abstract}

\section{Introduction}

"Nowadays, the trend of e-learning is increasing day by day and one of the tools to implement this concept is through Blended Learning. ${ }^{[2] " ~ " T h e ~ a r r i v a l ~ o f ~ W o r l d ~ W i d e ~}$ Web (WWW) has increased the demand for distance education $^{[3]}$ ".

Blended learning has long been studied and used in by educators and scholars. Most of the scholars agree that blended learning combines traditional face-to-face instruction and online learning, and brings a lot of convenience to both learners and pedagogues. However, until now, there is no consistent definition of it. Manjot Kaur listed different definitions from "the Holistic Perspective, the Educational Perspective, the Pragmatic Perspective, the Corporate Training Perspective and the Chief Learning Officer (CLO) Perspective ${ }^{[2] " ~ w h i l e ~}$ Maryam Tayebinik and Marlia Puteh ${ }^{[3]}$ listed different definitions of blended learning from a chronological sequence.

In 2020, COVID-19 swept the whole world and brought great impact on education, thus we have to think of blended learning again and try to implement it into practice right away. This paper focuses on literature review, advantages and challenges of blended learning, and creating high-quality translation courses with blended learning in teaching practice.

\section{Current Studies on Blended Learning}

\subsection{Background}

"Diversity, gender, cultural and personality differences among students have made University teaching a more challenging job than in previous years. ${ }^{[4]}$ "Therefore, how to make the class more interactive and motivating is like a headache for pedagogues who are committed to investigating new ways to overcome this problem. One of the way "is integrating an online component with traditional face-to-face instruction. ${ }^{[4]}$ ",

Blended learning has been studied more than a decade ago, which included its definition, advantages and challenges, ways to implementing blended learning, blended learning in higher education, so on and so forth. Maryam Tayebinik listed different scholars' definitions of blended learning in the paper, such as Driscoll, Delialioglu and Yildririm, Bonk, Picciano, Rovai and Jordan, Graham, and he "applies Colin and Moonen's definition of blended learning i.e. 'a hybrid of traditional face-to- face and online learning so that instruction occurs both in the classroom and online, and where the online component 
becomes a natural extension of traditional classroom learning'[5]"'. Manjot Kaur listed definitions according to five different perspectives. Abeer Ali Okaz, in the paper, also quoted different definitions of many scholars' ie, Driscoll, Kanuka, Singh etc. to describe "what blended learning is ${ }^{[4]}$ ". This paper thinks that even though there is no unity of definition, we can still find their similarity, which is: "a mix/hybrid/combination of face-to-face interaction and online learning".

\subsection{Relationship Among Blended Learning, Face- To-Face Learning And Online Learning}

To better understand the definition of blended learning, it's necessary to figure out the relationship among them. In this paper, blended learning can be described with the following figure (Figure 1):

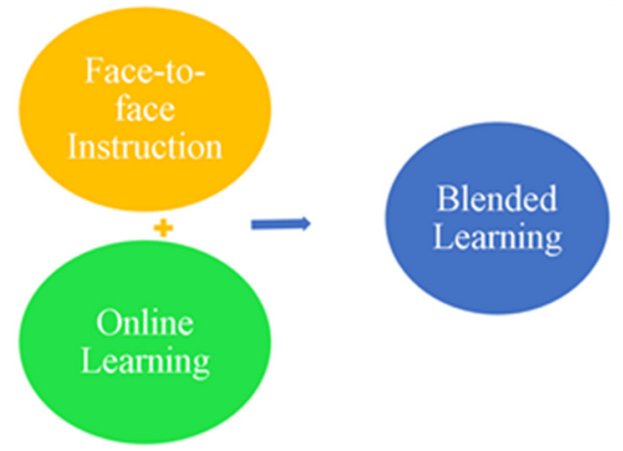

Fig 1. What is Blended learning?

From figure 1, face-to-face instruction plus onlinelearning equals to blended learning, but in fact, the relationship among them is more complicated, which can be explained in Figure 2:

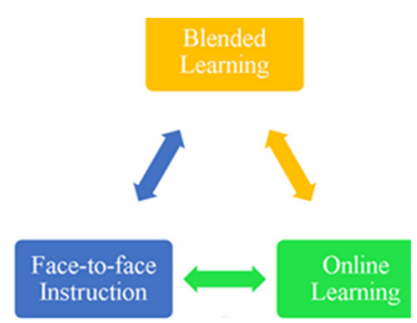

(Figure 2a)

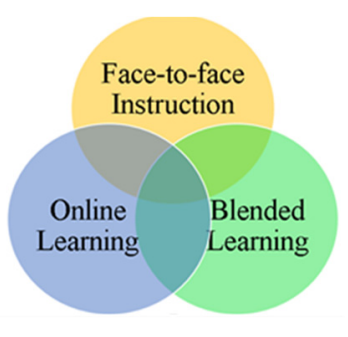

(Figure 2b)
Fig 2. Relationship among Face-to-face Instruction, Online Learning and Blended Learning

Some scholars agree that blended learning includes face-to-face instruction and online learning, but in this paper, just as presented in Figure 2, thought that their relationship is beyond that. In Figure $2 \mathrm{a}$, we can see that face-to-face instruction, online learning and blended learning form a virtuous circle: face-to-face instruction and online learning are the foundation of blended learning; meanwhile, blended learning promotes face-to-face instruction, and online learning and face-to-face instruction also facilitate the development of each other. In Figure 2b, the relationship among them is more obvious: they overlap with each other while they all have their own specialities. They are different but complementary with each other.

\subsection{Current Situation Of Blended Learning}

This paper, to better make it certain the current situation of blended learning in education, surveyed some students and teachers (see Table 1 and Table 2).

Table1. QUESTIONNAIRE TO STUDENTS IN BLENDED LEARNING $\quad(x=113)$

\begin{tabular}{|c|l|l|l|}
\hline Statement & $\begin{array}{c}\text { Agree } \\
(\%)\end{array}$ & $\begin{array}{c}\text { Disagree } \\
(\%)\end{array}$ & $\begin{array}{c}\text { No } \\
\text { opinion } \\
(\%)\end{array}$ \\
\hline $\begin{array}{c}\text { I have experienced } \\
\text { blended learning. }\end{array}$ & 75.22 & 9.73 & 15.04 \\
\hline $\begin{array}{c}\text { I could control my } \\
\text { learning pace. }\end{array}$ & 72.57 & 18.58 & 8.85 \\
\hline $\begin{array}{c}\text { Blended learning could } \\
\text { better help my studies. }\end{array}$ & 84.96 & 6.19 & 8.85 \\
\hline $\begin{array}{c}\text { I am an active learner } \\
\text { now. }\end{array}$ & 56.64 & 29.2 & 14.16 \\
\hline $\begin{array}{c}\text { I hope there will be } \\
\text { more blended courses. }\end{array}$ & 79.65 & 6.19 & 14.16 \\
\hline $\begin{array}{c}\text { Blended learning } \\
\text { promote the relationship } \\
\text { among institute, } \\
\text { students and teachers. }\end{array}$ & 85.84 & 4.42 & 9.73 \\
\hline
\end{tabular}

Table2. QUESTIONNAIRE TO TEACHERS IN BLENDED COURSES $\quad(x=70)$

\begin{tabular}{|c|c|c|c|}
\hline Statement & $\begin{array}{c}\text { Agree } \\
(\%)\end{array}$ & $\begin{array}{c}\text { Disagree } \\
(\%)\end{array}$ & $\begin{array}{c}\text { No } \\
\text { opinion } \\
(\%)\end{array}$ \\
\hline $\begin{array}{c}\text { I have taught } \\
\text { blended courses. }\end{array}$ & 60 & 27.14 & 12.86 \\
\hline $\begin{array}{c}\text { Blended learning } \\
\text { really helps. }\end{array}$ & 81.43 & 1.43 & 17.14 \\
\hline $\begin{array}{c}\text { I have to spend } \\
\text { more time learning } \\
\text { new technology in } \\
\text { order to teach well. }\end{array}$ & 87.14 & 2.86 & 10 \\
\hline $\begin{array}{c}\text { Blended learning } \\
\text { promote the } \\
\text { relationship among } \\
\text { institute, students } \\
\text { and teachers. }\end{array}$ & 82.86 & 4.29 & 12.86 \\
\hline $\begin{array}{c}\text { I hope there will be } \\
\text { more blended } \\
\text { courses. }\end{array}$ & 75.71 & 12.86 & 11.43 \\
\hline
\end{tabular}

From Table 1, it is clear to see that most of the students have experienced blended class. For these students, they can control their learning space $(72.57 \%)$, that is to say, a majority of them can manage their time and be active learners $(56.64 \%)$. As for the effect of blended learning, $84.96 \%$ of them agreed that blended learning could develop their studies. In addition, students thought blended learning could promote the relationship among institute, students and teachers, that is to say, face-to-face 
instruction can be more interactive and motivating and the students will like their campus more.

However, except these positive answers, it is necessary to think about those negative answers. For example, $18.58 \%$ of the surveyed students thought they could not control their learning pace. Blended learning, in fact, requires the students to be qualified to learn by themselves. Otherwise, they won't be able to prepare for the class and review the lessons after the class. $29.2 \%$ of the surveyed students thought they weren't active learners. As for them, pedagogues need to figure out the reasons and take actions to motive them in blended learning.

From Table 2, it's also obvious that most of the teachers have taught blended courses and they think blended learning really helps in teaching. But they also think they have to spend more time learning new technologies. For most of the teachers, they hope there will be more blended class.

"Online learning is one of the fastest growing trends in educational uses of technology. By the 2006-2007 academic year, $61 \%$ of US higher education institutions offered online courses. In fall 2008 , over 4.6 million students - over one quarter of all U.S. higher education students - were taking at least one online course. ${ }^{[6] "}$ "From the questionnaire, this paper agrees that blended learning, to some degree, is popular and beneficial for students and teachers. However, there is still a long way to fully play the roles of blended learning.

From the survey, this paper agrees: blended class is popular in the current education; most of the teachers and students have experienced blended class, and they give positive respond to it.

\subsection{Merits And Challenges of Blended Learning}

"Online learning has become popular because of its potential for providing more flexible access to content and instruction at any time, from any place ${ }^{[6] "}$. Blended learning does have many advantages, i.e: "to overcome the shortcomings of online instruction and exploit various instructional process and delivery strategies in order to increase learners' satisfaction as well as boosting the learning outcomes ${ }^{[3]}$ ".

"Blended learning has potential to improve learning but there are also challenges ${ }^{[7] "}$ ": "the expectation that fewer classes meant less work, inadequate time management skills, problems with accepting responsibility for personal learning, and difficulty with more sophisticated technologies ${ }^{[5]}$ ".

This paper thinks that merits of blended learning include flexibility in learning environments, continuous learning, various resources, supplement for face-to-face instruction, and lubricant among institutions, teachers and students. Meanwhile, it has challenges because it needs the students to be self-discipline, qualified to learn by oneself, learn new technologies, and to be critical. And pedagogues need to spend more time learning new teaching technologies.

\section{Blended Learning of High-quality Translation Courses}

In 2018, Wuyan delivered a speech about high-quality

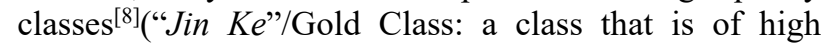
quality, and such class must be advanced, challengeable, and creative.). From that on, a lot of pedagogues try to develop blended courses of high-quality.

As for traditional translation classes, teachers would mainly teach in the classroom with powerpoint, explaining some translation theories, principles and corresponding examples. The students don't have much time to exercise or think about the translations, which, as a consequence, makes the class boring and tiring. However, blending the class will make things different. Students could preview the lessons by themselves when they have time, at any place. Thus, they could have better readiness for the faceto-face instruction. However, to develop a motivating and effective blended translation course with high quality, there are so many things for institutions, teachers, and students to do.

Elizabeth Stacey and Philippa Gerbic summarized "factors that promote successful blended learning ${ }^{[7]}$ " by quoting from sharpe, Benfield, Robert, Francis, Tabor, Garrison and Vaughan. For example, they quote from Tabor: "It is important that the institutional building blocks are in place including organisational readiness, sufficient technical resources, motivated faculty, good communication and feedback channels with students ${ }^{[7]}$ ". As for the institutions, this paper agrees that they should provide hardware and technological trainings. The advanced hardware and technology are the foundation for developing a blended course.

As for the teachers, there are more for them to do. They have to learn how to use new software or applications, to search for new resources and create online class for the students to preview before the class. They also need to distinguish the content that will present in the class from the online class, which makes them more tired with more workloads. After the face-to-face instruction, they have to check the students' online tasks. For example, a teacher who wants to talk about comparing two versions of $A$ Dream of the Red Mansion, he should at first give the background information of this book and its translation, introduction to the translators and their versions respectively, some translation-related questions like "what kind of theory do the translators use? What's the difference? Which one is better and why? Can you find some typical translations and compare them in your own way". Then the teacher should design different content for the face-to-face instruction. More precise translation examples, analysis and comparison are welcomed in the classroom. Students can discuss with each other and present their own understanding of different translations. Thus, the class will be more interactive and motivating; the students will be more critical. Finally, after the class, the teacher should design some corresponding tasks for the students to finish as well as offer more resources to the students to broaden their horizon.

When regarding students, Elizabeth Stacey and Philippa Gerbic quoted from Tabor that "Students' 
learning maturity and readiness for blending learning with its demands for independent learning must be considered $^{[7]}$ ". Therefore, the students should well be prepared for the class, or they won't catch up with the class. To learn better with blended class, students should also learn new technologies and the use of the applications. For example, to have the translation class, the students must finish the online tasks before the class. They need to refer to some theoretical books so as to comparing two versions of the book A Dream of the Red Mansion. They also need to read carefully to compare some typical sentences and give their own understanding. While in the class, they have not only to listen to the teacher, share their own understanding, but also analyze their classmates' idea and be critical.

To develop a high-quality blended translation class with is not easy for institutions, teachers and students. Allison Rossett, Felicia Douglis, and Rebecca V. Frazee gave out some suggestions: "Deliver assets and guidance; Work cross-functionally; Encourage independence and conviviality; Focus on flexible options for employees and customers; Put people in the middle of the blend; Communicate, communicate, communicate; Embrace redundancy; take on key initiatives and measure results; Recognize this as an opening salvo in the quest for effective blends ${ }^{[9]}$,"

\section{Conclusion}

In the post-epidemic era, face-to-face instruction can't meet our needs any more. We have to develop various forms of teaching and learning. And blended learning is a good choice. Blended learning is now popular and beneficial for teachers and students. It brings convenience and flexibility in the distance education, provides more resources for the students, supplement face-to-face instruction, and cultivate students' critical thinking ability. However, it still has some challenges to overcome. To continually learn new technologies and to finish extra workloads and tasks etc. makes teachers and students tired. With blended class, a high-quality blended translation class is also possible. In addition, there are strategies to have a successful blended class.

\section{Acknowledgment}

This research was financially supported by a research project from Wuhan Business University in 2018, Grant No.: 2018KY012.

\section{References}

1. Mitchell A, Honore S . Criteria for successful blended learning[J]. Industrial \& Commercial Training, 2007, 39(2-3):143-149.

2. Kaur M . Blended Learning . Its Challenges and Future $[\mathrm{J}]$. Procedia - Social and Behavioral Sciences, 2013, 93:612-617.

3. M Tayebinik M , Puteh M . Blended Learning or ELearning?[J]. Social Science Electronic Publishing.
4. Okaz, Ali A . Integrating Blended Learning in Higher Education[J]. Procedia - Social and Behavioral Sciences, 2015, 186:600-603.

5. Vaughan N. Perspectives on Blended Learning in Higher Education[J]. International Journal on ELearning, 2007, 6(January):81-94.

6. Means B, Toyama Y, Murphy R, et al. The Effectiveness of Online and Blended Learning: A Meta-Analysis of the Empirical Literature[J]. Teachers College Record, 2005, 115(3).

7. Stacey E, Gerbic P . Success factors for blended learning[C]// Conference of the Australasian Society for Computers in Learning in Tertiary Education. Deakin University : ASCILITE, 2008.

8. Wen Qiufang, On the academic positioning of foreign language education and the identity of Chinese foreign language teacher $[\mathrm{J}]$. Foreign Language Education in China, 2019:3-10, 90.

9. Rossett A, Douglis F, Frazee R V . Strategies for Building Blended Learning[J]. 2006. 